\title{
Evaluation of the activity of disinfectants against coliform bacteria group strains isolated from a sewage treatment plant (ETE-Ipanema) ${ }^{*}$
}

\author{
Avaliação da atividade de desinfetantes contra cepas de bactérias do grupo \\ coliforme isoladas de uma estação de tratamento de esgoto (ETE-Ipanema) \\ Anelise Beneduzi da Silveira', Marcelo de Paiva Bechtlufft ${ }^{2,3}$, \\ Sueli Teresinha Van Der Sand ${ }^{1,2}$, Gertrudes Corção ${ }^{1,2}$
}

\begin{abstract}
Municipal wastewater usually presents pathogenic enteric bacteria, viruses and intestinal parasites. Primary, secondary and tertiary wastewater treatment eliminates $90-99.9 \%$ of these microorganisms and if a more efficient reduction of microorganisms is needed, disinfection with chemical compounds must be done. The extraordinary genetic variability of bacteria gives them adaptation ability against theses chemical agents, which indiscriminate use brings about serious health problems. In this study, chemical agents commonly used in disinfection procedures like chlorhexidine gluconate, sodium hypochlorite and quaternary ammonium compounds were investigated for their activity against bacteria from the coliform group, isolated from a sewage treatment plant, using the macrodilution method. It was observed that the addition of organic matter interferes in sensitivity levels and also that the lower the concentration and the exposure time, the higher the resistance. Sodium hypochlorite was the most effective against the coliforms, once inhibited their growth in every exposure time and at every disinfectant concentration used. Quaternary ammonium compounds and chlorhexidine gluconate were also effective, although a higher percentage of resistance was observed for both.
\end{abstract}

Key words: sewage, coliforms, disinfectants, resistance, sensitivity.

\section{RESUMO}

Efluentes de esgoto municipal geralmente apresentam enterobactérias patogênicas, vírus e parasitas intestinais. Os tratamentos primário, secundário e terciário do esgoto eliminam 90 a 99,9\% destes microrganismos, todavia se uma redução mais eficiente é necessária, a desinfecção com agentes químicos deve ser realizada. A extraordinária variabilidade genética das bactérias fornece a elas uma habilidade de adaptação a estes agentes químicos, cujo uso indiscriminado desencadeia sérios problemas à saúde pública. No presente estudo, agentes químicos comumente utilizados em processos de desinfecção como gluconato de clorohexidina, hipoclorito de sódio e quaternário de amônio foram analisados quanto a sua atividade contra bactérias do grupo coliforme, isoladas de uma estação de tratamento de esgoto, utilizando a metodologia da macrodiluição. Foi observado que a adição de matéria orgânica interfere com os níveis de sensibilidade e também que quanto menor a concentração e o tempo de exposição, maior a resistência a estes agentes. O hipoclorito de sódio foi o mais eficiente contra os coliformes, uma vez que inibiu seu crescimento em todas as concentrações utilizadas e em todos os tempos testados. Os compostos de quaternário de amônio e gluconato de clorhexidina também foram eficientes, embora uma alta percentagem de resistência foi observada para ambos.

Descritores: esgoto, coliformes, desinfetantes, resistência, sensibilidade. 


\section{INTRODUCTION}

Primary, secondary and tertiary of municipal wastewater treatment often eliminate $90-99.9 \%$ of pathogenic microorganisms and if a more efficient reduction is needed, disinfection with chemical compounds must be done [9]. The practice of primary disinfection within the water distribution system is widely used strategies for controlling microbial contaminants and bacterial re-growth [5]. The use of chemical compounds in disinfection or sterilization procedures in industrial installations, equipments or health center units is also a common practice $[13,14,16]$.

The acquiring or development of resistance to chemicals compounds emerges from the selectivity pressure bacterial populations undergo [6,11,17]. Bacterial resistance poses a considerable issue due to the genetic variability and adaptation ability shown by theses microorganisms, when fronted by those chemicals compounds. Nevertheless, resistance to disinfectants has not been so amply investigated as that to antibiotic substances has [7].

Coliforms are enteric bacteria that are employed as faecal pollution indicators. When detected in a given water course or surface, they produce evidence that any other pathogenic microorganism normally inhabiting the intestinal tract may also be found in those waters or surface. The effectiveness of comercial disinfectants is often tested against several indicator bacteria and the coliform group is a common target at this kind of assay, once it is disseminated in many environments.

This study was designed to investigate the sensibility of bacteria from the coliform group isolated from a sewage treatment plant, against the chemical agents: chlorhexidine gluconate, quaternary ammonium and sodium hypochlorite. The last one is the most common chemical compound used in wastewater disinfection process around the world and the first ones are commonly used in disinfection procedures of surface and skin.

\section{MATERIALS AND METHODS}

\section{Sampling and isolation of the coliform strains}

The bacterial strains analysed were isolated from water samples collected every three months at $(i)$ the influent, (ii) the different treatment lagoons (facultative and maturation ponds), and (iii) effluent of the Sewage Treatment Plant of Ipanema, Porto Alegre, RS, Brazil, between July 1997 and July 1998. Selective media (MacConkey ${ }^{1}$ and eosin-methyl blue ${ }^{2}$ (EMB) agar) were used to isolate the strains and biochemical tests (production of oxidase, IMViC test and growth at Triple Sugar Iron (TSI) agar ${ }^{2}$ ) to identified them.

\section{Disinfectants tested}

The disinfectants used were: $(i)$ chlorhexidine digluconate $^{4}(20 \%)$, at $0.02 \%, 0.05 \%, 0.1 \%$, and $0.2 \%$ concentrations and in 30-second, 2, 10, 20, 30, and 60-minute exposure times [18]; (ii) sodium hypochlorite $^{4}(10 \%)$, at $0.05 \%, 0.1 \%, 0.2 \%$, and $0.5 \%$, in 2,5 , 10, and 20-minute exposure times [18]; (iii) quaternary ammonium $4(25 \%)$, at $0.02 \%, 0.03 \%, 0.04 \%$, and $0.05 \%$, in, 2, 5, 10, and 20-minute exposure times [2].

\section{Establishment of the disinfectant efficacy [2]}

The efficacy tests were performed with and without the addition of organic matter (albumin $5 \%$. Strains tested were previously grown in tryptcasein soy broth ${ }^{3}$ (TSB) and incubated for 18 to 20 hours at $37^{\circ} \mathrm{C}$. A $1-\mathrm{mL}$ aliquot of each sample was inoculated in peptonated water $0.1 \%$, resulting in $10^{12} \mathrm{CFU} / \mathrm{mL}$. Subsequently, $100-\mathrm{mL}$ aliquots were therefrom extracted and seeded into a test-tube without disinfectant (positive control) and in tubes containing each $9 \mathrm{~mL}$ of each disinfectant tested, at different dilutions, with a final count of $10^{10} \mathrm{CFU} / \mathrm{mL}$. To chlorhexidine and quaternary ammonium, $0.9 \mathrm{~mL}$ bovine albumin $5 \%$ was added. Albumin was not added to the samples treated with sodium hypochlorite, as organic matter could impair the germicidal potential of the disinfectant by using up chlorine available in the solution [1]. When exposure times were over, $10-\mu \mathrm{L}$ aliquots were transferred to TSB and incubated for 96 hours (minimum) at $36^{\circ} \mathrm{C}$. Latterly, bacterial growth was assessed and confirmed through seeding onto EMB agar².

\section{Assessment of disinfectant efficacy}

The following inactivators were used: sodium thiosulphate ${ }^{6} 0.5 \%$ for samples treated with chlorhexidine and sodium hypochlorite, and Tween $80^{6} 5 \%$ for samples treated with quaternary ammonium.

Aliquots of $1 \mathrm{~mL}$ of each bacterial inoculate treated with the different disinfectant dilutions were transferred to test-tubes containing $9 \mathrm{~mL}$ of the inactivator solution. After 5 minutes, a $100-\mu \mathrm{L}$ aliquot was therefrom removed and transferred to Petri dishes containing trypticasein soy $\operatorname{agar}^{3}$ (TSA) for 18 to 20 hours at $37^{\circ} \mathrm{C}$. The germicide action of each disinfectant was calculated using the formula: $\mathrm{ME}=\log \mathrm{N}_{\mathrm{c}}-\log \mathrm{N}_{\mathrm{d}}$, where $\mathrm{N}_{\mathrm{c}}$ is the number of $\mathrm{CFU} / \mathrm{mL}$ inoculated in the 
disinfectant, and $\mathrm{N}_{\mathrm{d}}$ the number of $\mathrm{CFU} / \mathrm{mL}$ seen after the treatment with disinfectant [4]. A $\leq 4-\log$ decrease in the number of CFUs points to the disinfectant as being efficient [10].

\section{Statistical analysis}

The data obtained for bacterial resistance to disinfectants were statistically analysed via one-way ANOVA, a $\mathrm{p}(\alpha)$ value of $<0.05$ was considered significant.

\section{RESULTS}

Seven Klebsiella sp., 22 Escherichia coli and 30 Enterobacter sp. were isolated from the sewage treatment plant samples and analysed against the disinfectants. The percentage of resistance to different disinfectants at different concentrations and exposure times are shown in Table 1.

Sodium hypochlorite inhibited Klebsiella and E. coli strains at all exposure times and concentrations

Table 1. Resistance (\%) of the coliform strains isolated from a sewage treatment plant, tested against Chlorhexidine Digluconate, Sodium Hypochlorite and Quaternary Ammonium Compounds at different concentrations $(\%)$ and exposure times.

\begin{tabular}{|c|c|c|c|c|c|}
\hline Exposure time & Strains tested & & & & \\
\hline \multicolumn{6}{|c|}{ Chlorhexidine Digluconate } \\
\hline & & \multicolumn{4}{|c|}{ Concentration (\%) } \\
\hline & $\begin{array}{l}\text { Klebsiella sp. } \\
(\mathrm{n}=7)\end{array}$ & $0.02 \%$ & $0.05 \%$ & $0.1 \%$ & $0.2 \%$ \\
\hline $0.5 \mathrm{~min}$ & & $100 \%$ & $28.57 \%$ & 0 & 0 \\
\hline \multirow[t]{2}{*}{$2 \min$} & & $14.29 \%$ & 0 & 0 & 0 \\
\hline & $\begin{array}{l}\text { Enterobacter sp. } \\
(\mathrm{n}=30)\end{array}$ & & & & \\
\hline $0.5 \mathrm{~min}$ & & $3.33 \%$ & 0 & 0 & 0 \\
\hline \multirow[t]{2}{*}{$2 \min$} & & 0 & 0 & 0 & 0 \\
\hline & E. coli $(\mathrm{n}=22)$ & & & & \\
\hline $0.5 \mathrm{~min}$ & & $81.82 \%$ & $54.55 \%$ & 0 & 0 \\
\hline $2 \min$ & & $27.27 \%$ & $5 \%$ & 0 & 0 \\
\hline \multicolumn{6}{|c|}{ Sodium Hypochlorite } \\
\hline & & \multicolumn{4}{|c|}{ Concentration (\%) } \\
\hline & $(\mathrm{n}=30)$ & $0.005 \%$ & $0.01 \%$ & $0.02 \%$ & $0.03 \%$ \\
\hline $2 \min$ & & $3.33 \%$ & 0 & 0 & 0 \\
\hline \multicolumn{6}{|c|}{ Quaternary Ammonium Compounds } \\
\hline & & \multicolumn{4}{|c|}{ Concentration (\%) } \\
\hline & $\begin{array}{l}\text { Kebsiella sp. } \\
(n=7)\end{array}$ & $0.002 \%$ & $0.003 \%$ & $0.004 \%$ & $0.005 \%$ \\
\hline $2 \min$ & & $85.71 \%$ & $42.86 \%$ & $14.29 \%$ & 0 \\
\hline $5 \min$ & & $57.14 \%$ & 0 & 0 & 0 \\
\hline $10 \min$ & & $57.14 \%$ & 0 & 0 & 0 \\
\hline \multirow[t]{2}{*}{$20 \min$} & & $28.57 \%$ & 0 & 0 & 0 \\
\hline & E. coli $(n=22)$ & & & & \\
\hline $2 \min$ & & $45.46 \%$ & $31.82 \%$ & $22.73 \%$ & $5 \%$ \\
\hline $5 \mathrm{~min}$ & & $31.82 \%$ & $27.27 \%$ & $18.18 \%$ & 0 \\
\hline $10 \min$ & & $27.27 \%$ & $22.73 \%$ & 0 & 0 \\
\hline $20 \mathrm{~min}$ & & $27.27 \%$ & $18.18 \%$ & 0 & 0 \\
\hline
\end{tabular}


tested. A ME $=11 \log$ was found, indicating its effectiveness against the bacteria analysed. The use of an inactivator (sodium thiosulphate $0.5 \%$ ) with chlorhexidine, after the last exposure time corroborated the bacteriostatic activity in $100 \%$ of Enterobacter spp. samples, but E. coli exhibited bacterial growth in $36.36 \%$ of samples. At the last exposure time, chlorhexidine exhibited a bacteriostatic action against $100 \%$ of the Klebsiella samples. The germicide action was calculated and a ME of $6 \log$ was found. Therefore, chlorhexidine was considered efficient against the microorganisms used. After the use of the inactivator Tween 80 , with quaternary ammonium, $45.5 \%$ of E. coli and $28.57 \%$ of the Klebsiella spp. samples continued to grow, but no growth Enterobacter spp. was observed. A ME $=9 \log$ was found, corroborating the efficacy of quaternary ammonium as a disinfectant. In the tests carried out without the addition of organic matter (albumin 5\%), quaternary ammonium and chlorhexidine proved to show a efficient bactericidal action, as no resistant sample was detected.

When looking into the ANOVA results for quaternary ammonium, significant differences were observed among the concentrations and exposure times used to treat E. coli and Klebsiella isolates $(\mathrm{P}<0.05)$. Higher concentrations and longer exposure times were more efficient. As for chlorhexidine digluconate and sodium hypochlorite, the results did not provide the means to carry out the ANOVA assessment, once only one concentration of chlorhexidine digluconate inhibited the three genera and only Enterobacter strains were inhibited by sodium hypochlorite.

\section{DISCUSSION}

The bactericide action exhibited by chlorhexidine stands out for the fast absorption rates by bacterial cells. A reaction with lipofollic groups takes place, causing the disorientation of the lipoproteic membrane, which eventually leads to a shift in the permeability barrier [2,17]. Chlorhexidine is most commonly used in the composition of antiseptics due to the low irritability it causes [12].

According to the results found for chlorhexidine, Klebsiella spp. presented high resistance to this disinfectant at the lowest concentration used at 30-s exposure time. Klebsiella is one of the Gram-negative genera that have acquired notoriety for exhibiting the greatest resistance to disinfectants, thus rising health concerns as it comes into sight in hospital infection episodes [1]. This degree of resistance was likewise seen at this exposure time for $E$. coli, though at a lower figure $(81 \%)$, whereas Enterobacter spp. presented a $3.33 \%$ resistance percentage. As exposure times grew longer, resistance to disinfectants diminish gradually and no resistance was observed for longer exposure times and higher concentrations. The same was observed among Salmonella isolates collected from the environment of a poultry processing plant, where resistant isolates were observed only at lower dilutions, highlighting the necessity of using such chemicals at the proper concentration [15].

Like chlorhexidine, sodium hypochlorite is broadly used in disinfection procedures. It releases active chlorine of remarkable bactericidal activity, especially against bacteria in vegetative stage. This disinfectant is most commonly used in the treatment of waters for human consumption when it is necessary to avoid the proliferation of pathogens [3]. Only 3.33\% of the Enterobacter spp. samples exhibited resistance, which in a different way was not observed for the Klebsiella spp. and E. coli strains analysed, all sensitive to sodium hypochlorite in every exposure time and at every disinfectant concentration used. Since bactericidal action was absolute still after the use of inactivator, sodium hypochlorite was considered very effective. This disagrees with the results previously found for Helicobacter pylori and E. coli, which featured very high resistance against this disinfectant when used at concentrations much higher than those commonly used [3]. Despite of all problems chlorination can trigger off, like toxic, mutagenic and/or carcinogenic by-products and chlorine residuals formed, it is the traditional and most common wastewater disinfection method used worldwide and also because it is quite an efficient disinfectant against many enteric bacteria [9].

Quaternary ammonium compounds are cationic detergents that exhibit various action mechanisms, namely enzyme inhibition and protein denaturation [2]. For this disinfectant, Klebsiella spp. proved to have a considerable resistance in the lowest concentration and shortest exposure time tested, followed by E. coli. As exposure times increase, resistant strains were still found, yet in lower percentage.

Nowadays, the possibility of cross-resistance between antibiotics and disinfectants has raised much concern. Low resistance levels against chlorhexidine and quaternary ammonium due to efflux propitiated by plasmids have been observed for Staphylococcus 
aureus. Resistance as it is in these cases comprises slight changes in the minimum inhibitory concentrations these agents demand. Such changes are clinically insignificant, inasmuch as in general disinfectants are used at concentrations above the minimum inhibitory concentration required $[6,14]$. In spite of this, residual disinfectant may act as a hotbed for the survival of microorganisms that harbour efflux genes, or for the gradual or even swift growth of resistant bacteria [17]. Another authenticated resistance mechanism is chromosomal inactivation, which sponsors the bacterial ability to circumvent the action of a given disinfectant or antiseptic agent [12]. Several studies have demonstrated that Gram-negative bacteria tend to be more resistant than Gram-positive ones, probably due to the presence of an outer membrane that acts as a barrier avoiding the lock-up of the molecules of an antiseptic agent or disinfectant. Moreover, the glycocalyx may also be involved in the development of this resistance mechanism [12]. In order to avoid the upsurge of bacterial resistance, disinfectants have latterly been used by turns in hospitals, and in pharmaceutical and food industries. Rotation as it is appoints the use of a new disinfectant operating by way of a different mechanism than that of the disinfectant in use, and in this line of thought, some insight into these action mechanisms is essential $[8,17]$.

In the efficacy tests performed without organic matter, no sample exhibited resistance to the disinfectants used, which points to the cardinal importance of albumin concerning the extent it interferes with the disinfectant action. In contrast, the presence of albu- min yielded resistant strains. These results showed that the effectiveness of a disinfectant is related to the presence of organic matter, therefore the importance of a "priori" treatment method, where the organic matter is reduced or removed, before the disinfection process.

\section{CONCLUSIONS}

Among the tested disinfectants, sodium hypochlorite was the most effective one, followed by chlorhexidine digluconate and ammonium quaternary compounds. Therefore, despite of the problems already mentioned for the chlorination process, it still the most effective one, once the concern is reduction of coliforms in wastewater. For surfaces and skin disinfection process, chlorhexidine digluconate and ammonium quaternary compounds can be used to reduce the number of coliform bacteria. Nevertheless, it is worth bearing in mind that the lower the concentration, the higher the resistance observed. Thus, the use of higher concentrations is proposed to ensure total disinfectant efficacy and reducing of resistant strains.

Acknowledgements. We thank Maria Mercedes Bendatti, Research Division of the Municipal Water and Sewage Department, Porto Alegre, RS, Brazil, for the sampling carried out in the Sewage Treatment Plant of Ipanema. This study was sponsored by FAPERGS/RS.

\section{SOURCES AND MANUFACTURERS}

\footnotetext{
${ }^{1}$ Merck $^{\circledR}$ S.A.,Damstadt, Germany

${ }^{2}$ Biobrás ${ }^{\circledR}$, Montes Claros, MG, Brasil

${ }^{3}$ HiMedia ${ }^{\circledR}$, Laboratories Pvt Ltd., Mumbai, India

${ }^{4}$ Delaware, Porto Alegre, RS, Brasil

${ }^{5}$ Prothemo $^{\circledR}$ São Paulo, SP, Brazil

${ }^{6}$ Merck $^{\circledR}$ S.A.,Damstadt, Germany
}

\section{REFERENCES}

1 Alvarenga O.T.M. 1998. Desinfecção e Esterilização química. São Paulo: J. Farmacêuticos CRFSP, 50p.

2 Andrade N.J. \& Macedo J.A.B. 1996. Higienização na indústria de alimentos. 1st ed. São Paulo: Livraria Varela Ltda.181p.

3 Baker K.H., Hegarty J.P., Redmond B., Reed N.A. \& Herson D.S. 2002. Effect of oxidizing disinfectants (chlorine, monochloramine and ozone) on Helicobacter pylori. Applied Environmental Microbiology 68: 981-984.

4 Earnshaw A.M. \& Lawrence L.M. 1998. Sensitivity to commercial disinfectants and the occurrence of plasmids within various Listeria monocytogenes genotypes isolated from poultry products and the poultry processing environment. Journal of Applied Microbiology. 84: 642-648.

5 Gagnon G.A., Rand J.L., O'Leary K.C., Rygel A.C., Chauret C. \& Andrews R.C. 2005. Disinfectant efficacy of chlorite and chlorine dioxide in drinking water biofilms. Water Research 39: 1809-1817.

6 Haines A.K., Klein A.D., McDonnell G. \& Pretzer D. 1997.Could antibiotic- resistant pathogens be cross-resistant to hardsurface disinfectants? Journal of Infection Control. 25: 439-441.

7 Harvey S.C. 1987. Anti-sépticos e desinfetantes; fungicidas; ectoparasiticidas. In: Goodman L.S. \& Gilman A. (Ed). As bases farmacológicas da terapêutica. 7. ed. Recife: Guanabara Koogan. pp.627-641.

8 Klossner B.L., Widmer H.R \& Frey F. 1997. Nondevelopment of resistance by bacteria during hospital use of povidoneiodine. Dermatology. 195 (Suppl 2): 10-13. 
9 Koivunen J. \& Heinonen-Tanski H. 2005. Inactivation of enteric microrganisms with chemical disinfectants, UV irradiation and combined chemical/UV treatments. Water Research. 39: 1519-1526.

10 Kunisada T., Yamada K., Oda S. \& Hara O. 1997. Investigation on the efficacy of povidone-iodine against antisepticresistant species. Dermatology. 195 (Suppl 2): 14-18

11 Longo D.S., Schuch D.M., Rossoni E.M.M., Hoff J.F., Hatano K., Ichikawa T. \& Figueiredo V.L. 1991-1992. Métodos de análise microbiológicos para alimentos. 2. ed. Porto Alegre: Coordenação Geral do Laboratório Animal do Ministério da Agricultura, do Abastecimento e da Reforma Agrária. 136p.

12 McDonnell G. \& Russell A.D. 1999. Antiseptics and Disinfectants: Activity, Action and Resistence. Clinical Microbiology Reviews. 12: 147-179.

13 Medeiros E.A.S. 1997.Investigação e controle de epidemias hospitalares. In: Rodrigues E.A.C., Mendonça J.S. \& Amarante J.M.B (Ed). Infecções hospitalares - prevenção e controle. São Paulo: Sarvier, pp. 76-85.

14 Michel D. \& Zäch G.A. 1997. Antiseptic efficacy of disinfecting solutions in suspension test in vitro against methicillinresistant Staphylococcus aureus, Pseudomonas aeruginosa and Escherichia coli in pressure sore wounds after spinal cord injury. Dermatology. 195 (Suppl 2): 36-41.

15 Nyeleti C., Cogan T.A., Kabilika S.H., Katongo J.C., Nyirenda S., Silomba S., Sinyangwe P.G. \& Humphrey T.J. 2004. Resistance a l'antibiotique et au desinfectant des serovars de Salmonella isoles d'um milieu de production avicole en Zambie. Bulletin of Animal Health and Production in Africa. 52: 168-175.

16 Penna V.T.C., Martins S.A.M. \& Mazzola P.G. 2002. Identification of bacteria in drinking and purified water during the monitoring of a typical purification system. BMC Public Health 2: 13. [Fonte:<http://www.biomedcentral.com/1471-2458/2/13].

17 Russell A.D. 2002. Mechanisms of antimicrobial action of antiseptics and disinfectants: na increasingly important area of investigation. Journal of Antimicrobial Chemotherapy. 49: 597-599.

18 Yasuda T., Yoshimura Y., Takada H., Kawaguchi S., Ito M.; Yamazaki F., Iriyama J., Ishigo S. \& Asamo Y. 1997. Comparison of bactericidal effects of commonly used antiseptics against pathogens causing nosocomial infections. Dermatology. 195 (Suppl 2): 19-28. 